KeMAS 16 (1) (2020) 81-87
Jittp:/journal.unnes.ac.id/nju/index.php/kemas

\title{
Long Bean Leaf Extract for Improving Haematological Status of Female Adolescent with Anemia that Gets Fe Supplementation
}

\author{
Fatihah Wari Nurjanah ${ }^{1}$, Suharyo Hadisaputro ${ }^{2}$, Diyah Fatmasari ${ }^{\circledR 凶}$ \\ ${ }^{1}$ Midwifery, Post Graduated Program, Poltekkes Kemenkes Semarang, Indonesia \\ ${ }^{2}$ Poltekkes Kemenkes Semarang, Indonesia
}

\begin{tabular}{l} 
Article Info \\
\hline Article History: \\
Submitted January 2020 \\
Accepted March 2020 \\
Published July 2020 \\
\hline Keywords: \\
Long bean leaf extract, \\
Hemoglobin, \\
Hematocrit, \\
Erythrocytes, Female \\
Adolescent \\
\hline DoI \\
https://doi.org/10.15294/ \\
kemas.v16i1.23203
\end{tabular}

\begin{abstract}
The incidence of anemia among female adolescent in Indonesia is $48.9 \%$, due to menstruation, poor nutrition intake and worm investment. Long-term effects of anemia in female adolescent can occur stunting. Pharmacological anemia management by taking Fe supplements but these supplements can cause nausea. Nausea can be avoided by nonpharmacological anemia treatment by consuming Fe-containing foods such as long bean leaves. Long bean leaf contains Fe which can accelerate the absorption process of it in the body. The objective of the research was to analyze the effect of long bean leaf extract on changes in anemia status of female adolescent given Fe supplementation. Quasy experiment research design with pretest posttest with control group design. Data was collected for 14 days with 38 respondents. The treatment group was given $200 \mathrm{mg}$ / day long bean leaf extract and Fe supplement, while the control group was given Fe supplement. Hemoglobin, hematocrit and erythrocyte levels were measured before and after the intervention. Data analysis used paired and independent sample $t$ tests. The results showed the treatment group experienced increased levels of hemoglobin, hematocrit and erythrocytes by $1.45 \mathrm{gr} / \mathrm{dL}$ (p: 0.02), 3.61\% (p: 0.019) and $0.53 \mathrm{x} 106 / \mu \mathrm{l}$ (p: 0.013 ). 200 $\mathrm{mg} /$ day long bean leaf extract given to young women with anemia who received iron supplementation for 14 days improved hematological status as indicated by an increase in hemoglobin levels, hematocrit and erythrocyte counts.
\end{abstract}

\section{Introduction}

Anemia is a condition where the number of red blood cells or hemoglobin concentration falls below the normal threshold value so that it can damage the blood's capacity to carry oxygen throughout the body (Aulia et al., 2017). There are several classifications of anemia according to the causes such as Fe deficiency, vitamin A deficiency, vitamin B12 deficiency, folate and anemia due to chronic diseases. $\mathrm{Fe}$ deficiency anemia is the most common cause of anemia globally (Wulandari, 2015). Fe deficiency anemia is caused by a lack of Fe in the body which can be affected by insufficient $\mathrm{Fe}$ in the body, improper absorption of $\mathrm{Fe}$ to the body, being pregnant, having surgery and experiencing bleeding. The prevalence of anemia in women of reproductive age in the world is around $32.8 \%$ and had increased from 2010 to 2016 (The World Bank, 2016). The World Health Organization (WHO) targets a $50 \%$ reduction in women of reproductive age as one of six nutritional targets for 2025. Basic Health Research in 2018 reported that the incidence of anemia among female adolescent in Indonesia was $48.9 \%$ with the proportion of anemia in the age group of 15-24 years and 2534 years (Balitbangkes, 2018). The prevalence of anemia in Central Java in 2013 was 57.1\%, Fertile Age Women (wanita usia subur/WUS) reached $39.5 \%$ and in pregnant women by 43.5\% (Dinas Kesehatan Jawa Tengah, 2014). 
In 2015, the District Health Office of Sukoharjo conducted an examination of 1,200 young women, with $28.08 \%$ suffering from anemia (Dinas Kesehatan Kabupaten Sukoharjo, 2015). From these data, anemia mostly experienced by women so we need to take care of it since adolescence.

Women have a higher risk of anemia than men because women menstruate every month and many want ideal body shape so that they go on a diet that results in malnutrition (Yulaeka et al., 2017). Diets containing Fe inhibitors such as drinking iced tea and eating soybeans are associated with the incidence of anemia in female adolescent (Masthalina, 2015). Signs and symptoms of anemia such as hemoglobin levels are lower than normal, weak, lethargic, headaches, tinnitus, dizzy vision, gastrointestinal disorders and weak pulse. Anemia can be known by measuring hemoglobin levels, hematocrit and erythrocytes of the female adolescent (Khaidir, 2017). The effect of anemia causes a decrease in human immunity so that the disease easily attacks the body and the long-term impact of stunting can occur. Anemia can cause pregnant women to experience abortion, low birth weight, preeclampsia in primigravida and can cause perinatal death (Yulaeka et al., 2017). Anemia also affects the growth and development of children (Zulaekah et al., 2014). In order to avoid complications in the future, anemia must be overcome as early as possible.

There are two ways to overcome anemia in female adolescent, namely pharmacologically and non-pharmacologically. Pharmacological anemia prevention by consuming Fe tablets. The Indonesian government has conducted a program to control anemia in female adolescent by administering Fe tablets. One tablet contains $200 \mathrm{mg}$ of ferrous sulfate or $60 \mathrm{mg}$ of elemental $\mathrm{Fe}$ and $0,400 \mathrm{mg}$ of folic acid. Female adolescent get iron Fe with a preventative dose of 1 tablet a day for 10 days during menstruation and 1 tablet every week (Kemenkes RI, 2014). This program does not go well because female adolescents do not know the importance of taking the tablets and cause nausea. Lack of knowledge of female adolescent resulting in stopping consuming $\mathrm{Fe}$ tablets (Permatasari et al., 2018).

Non-pharmacological ways can be done by consuming foods that contain Fe which are easily found and can be processed in various ways. Examples of these foods are nuts, long bean leaf, papaya leaf, kale, spinach, moringa leaf, and others. These foods can increase haemoglobin if consumed regularly. Many researchers study about non-pharmacological treatment to overcome anemia by consuming it directly, made into food or extracts. Spinach and kale have been consumed by many people to overcome anemia but these plants are widely planted in areas that are exposed to pollution so that the nutritional content that should be beneficial is switched to be cautioned (Prastika et al., 2016).

Long bean leaf (Vigna sinensis L.) is one of the methods to overcome anemia that is easy for the people to obtain and is often consumed. The contents in long bean leaf are vitamins $\mathrm{A}$, $\mathrm{B}, \mathrm{C}$ and phosphorus. The Fe value of long bean per 100 grams is $0.7 \mathrm{mg}$ while the Leaves are $6.2 \mathrm{mg}$. Long bean leaves that contain Fe can increase hemoglobin levels, hematocrit levels and the amount of erythrocytes and vitamin C content can help facilitate reducing ferrous iron $(\mathrm{Fe} 3+)$ to ferrous $(\mathrm{Fe} 2+)$ so that it is easily absorbed in the intestine (Andarwulan \& Faradilla, 2012). Pharmacological and nonpharmacological methods can be combined with consumption of Fe tablets and long bean leaf extracts in order to accelerate Fe absorption.

\section{Method}

The design of this research was an experimental Quasy with a pretest posttest with control group design. The population of this research was young women who were in SMA Negeri (Senior High School) 3 Sukoharjo. A sample of 38 respodents was determined by purposive sampling. Inclusion criteria were female adolescent, willing to drink long bean leaf extract and Fe tablets or Fe tablets only for 14 days, anemia between 9-11 g / dL and not sick. The exclusion criteria in this study was being ill when the study was in progress. The sample was divided into two groups, namely the intervention group (19 respondents) and the control group (19 respondents). The intervention group was given $200 \mathrm{mg}$ long bean leaf extract (made in the Formulation laboratory at UGM) and Fe supplement while the control group was given $\mathrm{Fe}$ supplement 
only. Respondents consumed long bean leaf extract and Fe supplement for 14 days.

Researchers conducted data collection by observation, identification, filling in the questionnaire and blood tests. Measurement of hematological levels by means of a hematology analyzer was done in the Sarana Medika Surakarta laboratory. Data analysis used paired $\mathrm{t}$-test and independent sample $\mathrm{t}$ test. The processed data was used as a basis for discussion of statement problems and then presented in tabular form and conclusions could be drawn.

\section{Result and Discussion}

Characteristics of respondents as part of the variables to be compared between the intervention and control groups have been analyzed as follows.

The results of the homogeneity test of all variables showed $p$-value $>0.05$ so that there were no differences in the characteristics of respondents in the intervention and control groups.

Table 1. Frequency Distribution of Respondents Characteristics by Age, Menstruation and Worming

\begin{tabular}{llll}
\hline \multirow{2}{*}{ Characteristics } & Groups & p-value \\
\cline { 2 - 4 } Age & Intervention & Control & \\
Mean \pm SD & $16,42 \pm 0,507$ & $16,37 \pm 0,597$ & \\
Min \pm max & $16 \pm 17$ & $16 \pm 18$ & \\
Median & 16 & 16 & 0,815 \\
16 years & 11 & 13 & \\
17 years & 8 & 5 & 0,284 \\
18 years & 0 & 1 & \\
Menstruation & & & \\
Yes & $63,2 \%$ & $47,4 \%$ & 1 \\
No & $36,8 \%$ & $52,6 \%$ & \\
Worming & & & \\
Yes & $0 \%$ & $0 \%$ & \\
No & $100 \%$ & $100 \%$ & \\
\hline
\end{tabular}

Source : Primary data, 2019

Table 2. Hemoglobin Level Before and After Long Bean Leaf Extract Given in the Intervention Group and Control Group

\begin{tabular}{lccc}
\hline $\begin{array}{l}\text { Haemoglobin Level } \\
\text { (gr/dL) }\end{array}$ & \multicolumn{2}{l}{ Groups } & \multirow{2}{*}{$p$ value } \\
\cline { 2 - 3 } & Intervention & Control & \\
\hline Before Treatment & $10,12 \pm 0,57$ & $10,18 \pm 0,64$ & 0,732 \\
Mean \pm SD & $9,00 \pm 10,90$ & $9,00 \pm 11,00$ & \\
min \pm max & & & \\
After Treatment & $11,57 \pm 0,92$ & $10,93 \pm 0,67$ & 0,021 \\
Mean \pm SD & $10,00 \pm 13,30$ & $9,80 \pm 11,90$ & \\
min \pm max & & & \\
Deviation Average & $1,45 \pm 0,53$ & $0,74 \pm 0,40$ & 0,000 \\
Mean \pm SD & $0,50 \pm 2,40$ & $0,00 \pm 1,40$ & \\
min \pm max & 0,000 & 0,000 & \\
p-value (Paired t-test) & & & \\
\hline
\end{tabular}

Source : Primary data, 2019 
The average hemoglobin level before the treatment was given in the intervention group was $10.12 \mathrm{gr} / \mathrm{dL}$ where the lowest value was $9.00 \mathrm{gr} / \mathrm{dL}$ and the highest was $10.90 \mathrm{gr}$ / dL. After treatment, the mean hemoglobin level became $11.57 \mathrm{gr} / \mathrm{dL}$ where the lowest value was $10.00 \mathrm{gr} / \mathrm{dL}$ and the highest value was $13.30 \mathrm{gr} / \mathrm{dL}$. The average hemoglobin level before intervention for control group was $10.18 \mathrm{gr} / \mathrm{dL}$ where the lowest value was 9.00 gr / dL and the highest value was 11.00 gr / dL. After intervention, the mean hemoglobin level became $10.93 \mathrm{gr} / \mathrm{dL}$ with the lowest value of $9.80 \mathrm{gr} / \mathrm{dL}$ and the highest value of $11.90 \mathrm{gr} /$
dL. The mean difference of hemoglobin levels before and after treatment in the intervention group was $1.45 \mathrm{gr} / \mathrm{dL}$ while for the control group was $0.74 \mathrm{gr} / \mathrm{dL}$ with a p-value of 0,000 which means there was a significant difference of hemoglobin levels in the intervention group and control group.

The mean hematocrit level before treatment was given to the intervention group was $35.01 \%$ where the lowest value was $31.60 \%$ and the highest was $37.70 \%$. After treatment the mean of hematocrit level becomes $38.62 \%$ where the lowest value is $35.20 \%$ and the highest value is $42.50 \%$. The mean hematocrit level

Table 3. Hematocrit Level Before and After Long Bean Leaf Extract Given in the Intervention Group and Control Group

\begin{tabular}{|c|c|c|c|}
\hline \multirow{2}{*}{$\begin{array}{l}\text { Haematocrit Level } \\
(\%)\end{array}$} & \multicolumn{2}{|l|}{ Groups } & \multirow{2}{*}{$\mathrm{p}$ value } \\
\hline & Intervention & Control & \\
\hline $\begin{array}{l}\text { Before Treatment } \\
\text { Mean } \pm \text { SD } \\
\min \pm \max \end{array}$ & $\begin{array}{l}35,01 \pm 1,64 \\
31,60 \pm 37,70\end{array}$ & $\begin{array}{l}35,08 \pm 1,80 \\
31,50 \pm 37,80\end{array}$ & 0,896 \\
\hline $\begin{array}{l}\text { After Treatment } \\
\text { Mean } \pm \text { SD } \\
\min \pm \max \end{array}$ & $\begin{array}{l}38,62 \pm 2,17 \\
35,20 \pm 42,50\end{array}$ & $\begin{array}{l}37,01 \pm 1,85 \\
33,90 \pm 39,70\end{array}$ & 0,019 \\
\hline $\begin{array}{l}\text { Deviation Average } \\
\text { Mean } \pm S D \\
\min \pm \max \end{array}$ & $\begin{array}{l}3,61 \pm 1,19 \\
0,80 \pm 5,10\end{array}$ & $\begin{array}{l}1,92 \pm 0,97 \\
0,20 \pm 3,60\end{array}$ & 0,000 \\
\hline p-value (Paired t-test) & 0,000 & 0,000 & \\
\hline
\end{tabular}

Source : Primary data, 2019

Table 4 : Erythrocyte Level Before and After Long Bean Leaf Extract Given in the Intervention Group and Control Group

\begin{tabular}{|c|c|c|c|}
\hline \multirow{2}{*}{$\begin{array}{l}\text { Amount of Erythrocytes } \\
(\mu \mathrm{l})\end{array}$} & \multicolumn{2}{|l|}{ Groups } & \multirow{2}{*}{$\mathrm{p}$ value } \\
\hline & Intervention & Control & \\
\hline $\begin{array}{l}\text { Before Treatment } \\
\text { Mean } \pm \text { SD } \\
\min \pm \max \end{array}$ & $\begin{array}{l}3,80 \pm 0,22 \\
3,42 \pm 4,20\end{array}$ & $\begin{array}{l}3,80 \pm 0,22 \\
3,34 \pm 4,21\end{array}$ & 0,972 \\
\hline $\begin{array}{l}\text { After Treatment } \\
\text { Mean } \pm \text { SD } \\
\min \pm \max \end{array}$ & $\begin{array}{l}4,34 \pm 0,29 \\
3,89 \pm 4,87\end{array}$ & $\begin{array}{l}4,11 \pm 0,24 \\
3,60 \pm 4,42\end{array}$ & 0,013 \\
\hline $\begin{array}{l}\text { Deviation Average } \\
\text { Mean } \pm S D \\
\min \pm \max \end{array}$ & $\begin{array}{l}0,53 \pm 0,18 \\
0,12 \pm 0,80\end{array}$ & $\begin{array}{l}0,30 \pm 0,15 \\
0,09 \pm 0,69\end{array}$ & 0,000 \\
\hline p-value (Paired t-test) & 0,000 & 0,000 & \\
\hline
\end{tabular}

Source : Primary data, 2019 
before the treatment was given to the control group was $35.08 \%$ where the lowest value was $31.50 \%$ and the highest value was $37.80 \%$. After the treatment was given, the mean hematocrit level was $37.01 \%$ with the lowest value of $33.90 \%$ and the highest value of $39.70 \%$. The mean difference in hematocrit levels before and after treatment was given in the intervention group was $3.61 \%$ while the mean in the control group was $1.92 \%$ with p-value in the treatment group and the control group was 0,000 which meant there was a significant difference in hematocrit level in the treatment group and control group.

The mean of erythrocytes before the intervention was given in the treatment group was $3.80 \times 106 / \mu \mathrm{l}$ where the lowest value was $3.42 \times 106 / \mu \mathrm{l}$ and the highest was $4.20 \times 106$ / $\mu$ l. After intervention, the mean number of erythrocytes was $4.34 \times 106 / \mu \mathrm{l}$ where the lowest value was $3.89 \times 106 / \mu \mathrm{l}$ and the highest value was $4.87 \times 106 / \mu l$. The mean number of erythrocytes before the control group intervention was given $3.80 \times 106 / \mu \mathrm{l}$ where the lowest value was $3.34 \times 106 / \mu \mathrm{l}$ and the highest value was $4.21 \times 106 / \mu \mathrm{l}$. After intervention, the mean number of erythrocytes was $4.11 \times 106 /$ $\mu \mathrm{l}$ with the lowest value of $3.60 \times 106 / \mu \mathrm{l}$ and the highest value of $4.42 \times 106 / \mu \mathrm{l}$. The average difference in the level of erythrocytes before and after the intervention in the treatment group was $0.53 \times 106 /$ while the mean difference in the control group was $0.30 \times 106 / \mu$ with the $\mathrm{p}$-value in the treatment group and the control group 0,000 , which means that there were significant differences in erythrocytes level in the treatment group and control group.

The results of the analysis of confounding variables namely age, menstruation and helminthiasis in the treatment group giving long bean leaf extract and Fe supplement and control group giving Fe supplement only were found to be not too different or equivalent ( $p$-value $>0.05$ ). These results can be concluded that the confounding variables namely age, menstruation and helminthiasis in this study can be controlled.

$\mathrm{Fe}$ is the most important element in the formation of red blood cells. Fe supplements are taken to prevent and treat anemia in adolescents. Fe supplementation has side effects that cause gestational disorders for some people. These side effects include discomfort on epigastrium, nausea, vomiting and diarrhea. The dose of $\mathrm{Fe}$ supplementation is directly related to the frequency of side effects. Giving Fe supplements to some teens can cause constipation. Constipation can be relieved by consuming fiber such as bread, cereals, and agar (Jaya et al., 2020).

Fresh long bean leaf have an iron content of $6.2 \mathrm{mg} / \mathrm{100 \textrm {gr }}$. Fe content after extraction by maceration of $70 \%$ ethanol to $13,413 \mathrm{mg} / 100 \mathrm{gr}$ was tested using the AAS method. Long bean leaf extract is one source of Fe that is needed in the formation of hemoglobin, hematocrit and the level of erythrocytes. Fe content after extraction has doubled compared to fresh long bean leaf. Fe is an important part of hemoglobin which is an oxygen-carrying protein in the blood. Each globin molecule contains four heme groups. Each group contains ferrous iron atoms which quickly bind to one oxygen molecule. Each hemoglobin molecule carries four oxygen molecules (Rosidah \& Astuti, 2018). If $\mathrm{Fe}$ is reduced, blood cannot carry oxygen effectively. Oxygen is needed by the body for cells to function normally. Fe deficiency can cause anemia (Mukarromah, 2010) ; (C. P. Astuti et al., 2017).

Increased haemoglobin, haematocrit and erythrocytes level occur because long bean leaf have compounds that can help increase $\mathrm{Fe}$ in the blood. Long bean leaf contains iron, vitamin $\mathrm{C}$, vitamin $\mathrm{A}$ and proteins that can increase haemoglobin, haematocrit and erythrocyte level. Vitamin C plays a role in reducing the entry of ferric element in the small intestine. Vitamin $C$ can help make it easier to reduce ferrous iron $(\mathrm{Fe} 3+)$ to ferrous $(\mathrm{Fe} 2+)$ so that it is easily absorbed in the intestine because ferrous iron cannot be absorbed by the body. Vitamin $\mathrm{C}$ inhibits the formation of hemosiderin which is difficult to mobilize to free Fe when needed. Therefore, lack of vitamin $\mathrm{C}$ can more easily experience anemia. (Saputro \& Junaidi, 2015) ; (Y. Astuti, 2016).

In addition to vitamin $\mathrm{C}$, long bean leaf also contain vitamin A which functions to help absorption and mobilization of iron in the formation oferythrocytes. Vitamin A is related to erythrocytes in the production of erythrocytes, $\mathrm{Fe}$ and protein synthesis transferring both 
in mobilization and composing. Deficiency of vimanin A makes Fe deposits unable to be utilized in the erythropoesis process. Protein has an important role in the transportation of iron in the human body (Michelazzo et al., 2013). Protein can help globin synthesis and low protein can inhibit the process of hemoglobin synthesis resulting in iron deficiency. One of the glycoproteins synthesized in the liver is transferrin. This protein has a central role in the metabolism of Fe in the body, this is caused by transferrin transporting $\mathrm{Fe}$ in circulation to places that need. Ferritin is another protein that in normal conditions can store $\mathrm{Fe}$ and can be taken back for use in accordance with the needs of the body (Simanungkalit et al., 2019).

Increasedlevel of hemoglobin, hematocrit and erythrocytes in female adolescent are not only the influence of $\mathrm{Fe}$ supplements alone but other substances in the food consumed also affect the process of hemoglobin synthesis in the body. The Fe content in long bean leaf can help the formation of hemoglobin. Fe is a microelement that is essential for the body to act as a hemoglobin maker. In accordance with research on women workers, there is a significant relation between $\mathrm{Fe}$ consumption and elevated $\mathrm{Hb}$ levels (Rahmad, 2017).

Long bean leaf extract has several ingredients to help erythropoesis. Erythopoesis is carried out in the bone marrow with ingredients such as iron, vitamin B12, folic acid, vitamin B6, protein and other factors. The lack of one of these ingredients can result in decreased production of red blood cells or anemia. Protein plays a role in synthesizing globin which is part of hemoglobin and cellular protein (low protein intake will affect hemoglobin synthesis). Fe is part of the hem that functions for the preparation of hemoglobin (Petersson et al., 2018).

The process of $\mathrm{Fe}$ absorption occurs in the proximal duodenum jejunum to carry out protein synthesis so that in the ferric iron blood plasma is oxidized to ferrous iron blood plasma and then the transferitin binds to transport ferro into the bone marrow to join to form red blood cells. Hematocrit levels are very dependent on the number of erythrocytes because erythrocytes are the largest cell mass in the blood. Increasing and decreasing hematocrit levels in the blood can have an impact on blood viscosity. The greater the percentage of hematocrit levels, the blood viscosity will increase (Taimeh et al., 2017) ; (Hariyadi, 2015)

This research is in line with one in Surakarta, namely an increase in hemoglobin levels in pregnant women after giving 350 gram long bean leaves for 30 days (Prastika et al., 2016). Other research have shown increased levels of hematocrit in pregnant women after consuming green bean juice (Anastasia $\mathrm{S}$ et al., 2017).

The supplementation containing $\mathrm{Fe}$ substance without the support of other nutrients can influence the level of iron absorption in the body compared to the supplementation of $\mathrm{Fe}$ plus long bean extract.

\section{Conclussion}

The administration of $200 \mathrm{mg}$ long bean leaf extract per day for 14 days in anemic female adolescent given $\mathrm{Fe}$ supplementation improves hematological status (hemoglobin, hematocrit and erythrocyte levels).

For further research, it can be used as supporting data and can further investigate the extract of long bean leaf by examining in more detail such as nanoparticles.

\section{References}

Anastasia S,S., Soehartono, S., Ngadiyono, N., Muchlis, M., \& Dyah, D., 2017. Effect Of Consuming Green Bean (Phaseolus Radiatus) Juice on Maternal Blood Profile During Pregnancy. Belitung Nursing Journal, 3(5), pp.515-524.

Andarwulan, N., \& Faradilla, R.F., 2012. Senyawa Fenolik Pada Beberapa Sayuran Indigenous dari Indonesia. Seafast Center. IPB.

Astuti, C.P., Widyawati, M.N., \& Pujiastuti, S.E., 2017. The Effect of Iron Polymaltose Complex Tablet Administration to Increase Hemoglobin Level Among Pregnant Women With Anemia. Proceedings of the International Conference on Applied Science and Health, pp.246-251.

Astuti, Y., 2016. Hubungan antara Asupan Protein , Zat Besi dan Vitamin C dengan Kadar Hb pada Anak Umur (7-15) tahun di Desa Sidoharjo, Samigaluh, Kulon Progo, The Relation between Intake Protein, Ferrous and Vitamin C with $\mathrm{Hb}$ in Children (7-15) year old at Sidoharjo, Samigaluh, Kulon Progo. Mutiara Medika: Jurnal Kedokteran Dan Kesehatan, 10(2), 172-179. 
Aulia, G.Y., Udiyono, A., Saraswati, L.D., \& Adi, M.S., 2017. Gambaran Status Anemia Pada Remaja Putri di Wilayah Pegunungan Dan Pesisir Pantai (Studi di Smp Negeri Kecamatan Getasan dan Semarang Barat). Jurnal Kesehatan Masyarakat (e-Journal), 5(1), pp.193-200.

Balitbangkes., 2018. Hasil Utama RISKESDAS 2018. Balitbang Kemenkes RI.

Dinas Kesehatan Jawa Tengah., 2014. Profil Kesehatan Jawa Tengah.

Dinas Kesehatan Kabupaten Sukoharjo., 2015. Data Anemia dan KEK Remaja Putri.

Hariyadi, D., 2015. Efektifitas Vitamin C terhadap Kenaikan Kadar $\mathrm{Hb}$ pada Ibu Hamil di Kecamatan Pontianak Timur. Jurnal Vokasi Kesehatan, 1(5), pp.146-153.

Jaya, N., Sary, L., Putri, R. D., Kelurahan, S., Murni, D., Tumijajar, K., Tulang, K., \& Barat, B., 2020. Manfaat Bayam Merah (Amaranthus Gangeticus) Untuk Meningkatkan Kadar Hemoglobin pada Ibu Hamil. Jurnal Kebidanan Malahayati, 6(1), pp.1-7.

Kemenkes RI., 2014. Peraturan Menteri Kesehatan RI Nomor 88 Tahun 2014 Tentang Standar Tablet Tambah Darah Bagi Wanita Usia Subur dan Ibu Hamil.

Khaidir, M., 2017. Anemia defisiensi besi. Jurnal Kesehatan Masyarakat Andalas, 2(1), pp.140-145.

Masthalina, H., 2015. Pola Konsumsi (Faktor Inhibitor Dan Enhancer Fe) Terhadap Status Anemia Remaja Putri. Jurnal Kesehatan Masyarakat, 11(1), pp.80-86.

Michelazzo, F.B., Oliveira, J.M., Stefanello, J., Luzia, L.A., \& Rondó, P.H.C., 2013. The Influence of Vitamin A Supplementation on Iron Status. Nutrients, 5(11), pp.4399-4413.

Mukarromah, S.B., 2010. Pengaruh Senam Aerobik Intensitas Sedang Terhadap Kadar Eritrosit dan Hematokrit Darah. Prosiding Seminar Nasional \& Internasional. Universitas Muhammadiyah Semarang

Permatasari, T., Briawan, D., \& Madanijah, S., 2018. Efektifitas Program Suplementasi Zat Besi pada Remaja Putri di Kota Bogor. Media Kesehatan Masyarakat Indonesia, 14(1), pp.1-8.

Petersson, K., Jakobsson, O., Ohlsson, P., Augustsson, P., Scheding, S., Malm, J., \& Laurell, T., 2018. Acoustofluidic Hematocrit Determination. Analytica Chimica Acta, 1000, pp.199-204.
Prastika, D.A., Setiani, O., \& Sumarni, S., 2016. Pengaruh Konsumsi Daun Kacang Panjang Terhadap Peningkatan Kadar Hemoglobin Pada Ibu Hamil TM II Dengan Anemia Di Wilayah Kerja Puskesmas Polanharjo Kabupaten Klaten. Jurnal Kebidanan Dan Kesehatan Tradisional, 1(2).

Rahmad, A.H., (2017). Pengaruh Asupan Protein dan Zat Besi (Fe) terhadap Kadar Hemoglobin pada Wanita Bekerja. Jurnal Kesehatan, 3(5), pp.515-524.

Rosidah., \& Astuti, L., 2018. Perbandingan Kadar Hematokrit Mikrokapiler Perokok Aktif dan Perokok Pasif Mahasiswa Akademi Analis Kesehatan Delima Husada Gresik. Jurnal Sains, 8(15).

Saputro, D.A., \& Junaidi, S., 2015. Pemberian Vitamin C pada Latihan Fisik Maksimal dan Perubahan Kadar Hemoglobin dan Jumlah Eritrosit. JSSF (Journal of Sport Science and Fitness), 4(3).

Simanungkalit, S.F., Arini, F.A., \& Frequency, S.Q.-F., 2019. Gambaran IMT/U , Asupan Zat Besi ( $\mathrm{Fe}$ ), dan Inhibitor Zat Besi ( Fe ) Dengan Anemia Remaja Putri di SMA Muhammadiyah 7 Sawangan, Depok Tahun 2018. Medika Respati: Jurnal Ilmiah Kesehatan 14(3), pp.255-263.

Taimeh, Z., Koene, R.J., Furne, J., Singal, A., Eckman, P.M., Levitt, M.D., \& Pritzker, M.R., 2017. Erythrocyte Aging as a Mechanism of Anemia and a Biomarker of Device Thrombosis in Continuous-Flow Left Ventricular Assist Devices. Journal of Heart and Lung Transplantation, 36(6), pp.625-632.

The.World.Bank., 2016. Prevalence of Anemia Among Women of Reproductive Age (\% Of Women Ages 15-49.

Wulandari, P., 2015. Honey to Prevent Iron Deficiency Anemia in Pregnancy. Jurnal Majority 4(3), pp.90-95.

Yulaeka, Y., Suwondo, A., Suherni, T., Hadisaputro, S., \& Anwar, M.C., 2017. Effect of Consuming Guava Leaves (Psidii Folium) Extract on The Level of Blood Profile in Teenage Girls at Vocational High School of Palebon Semarang, Indonesia. Belitung Nursing Journal, 3(5), pp.548-554.

Zulaekah, S., Purwanto, S., \& Hidayati, L., 2014. Anemia Terhadap Pertumbuhan Dan Perkembangan Anak Malnutrisi. Jurnal Kesehatan Masyarakat, 9(2), pp.106-114. 